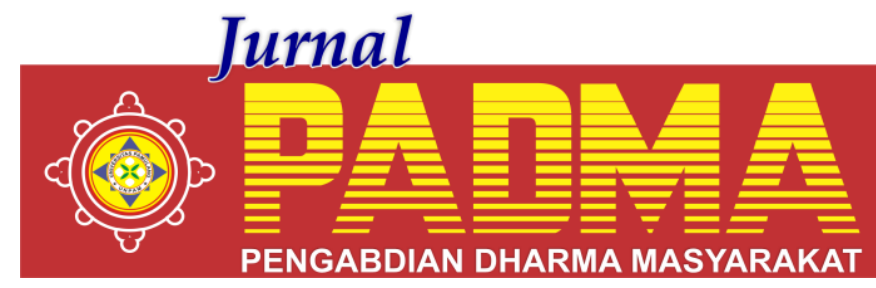

VOLUME 1, NOMOR 4, OKTOBER 2021

\title{
PELATIHAN PENGEMBANGAN DIRI BAGI PEMUDA KARANG TARUNA DESA
}

\author{
${ }^{1 *}$ Irfan Efendi, ${ }^{2}$ Galuh Rakasiwi, ${ }^{3}$ Alfian Hadi Saputra, ${ }^{4}$ Sulton Aziz, ${ }^{5}$ Tata Jaya Putra \\ Universitas Pamulang, Tangerang Selatan, Banten, Indonesia \\ *iefendi72@gmail.com
}

\begin{abstract}
Abstrak
Tujuan Pengabdian Kepada Masyarakat (PKM) Mahasiswa ini adalah untuk memberikan pengetahuan dan pemahaman kepada elemen Masyarakat, Pengembangan diri merupakan kebutuhan penting bagi setiap manusia. Dalam perspektif psikologi perkembangan, pengembangan diri berhubungan dengan potensi diri yang dioptimalkan secra efektif dan berkelanjutan. Dan untuk masyarakat khususnya generasi muda karang taruna desa cidokom, kecamatan gunung sindur, Kabupaten bogor, jawa barat. Sebagai organisasi sosial kepemudaan karang taruna merupakan wadah pembinaan dan pengembembangan serta pemberdayaan dalam upaya mengembangkan kegiatan ekonomi produktif dengan memaksimalkan potensi yang tersedia dilingkungan sumber daya manusia maupun sumber daya alam yang tersedia.
\end{abstract}

Kata Kunci: Pengembangan Diri, Karang Taruna

\section{Abstract}

The purpose of this student community service (PKM) is to provide knowledge and understanding to elements of society. Self-development is an important need for every human being. In the perspective of developmental psychology, self-development relates to self-potential that is optimized effectively and sustainably. And for the community, especially the young generation of youth organizations in Cidokom Village, Gunung Sindur District, Bogor Regency, West Java. As a youth social organization, Karang Taruna is a forum for fostering and developing as well as empowering in an effort to develop productive economic activities by maximizing the potential available in the environment of human resources and available natural resources.

Keywords: Self Development, Youth Organization

\section{PENDAHULUAN}

Manajemen merupakan salah satu program studi di Universitas Pamulang. Program studi ini memiliki andil dalam mencetak lulusan yang berkarakter serta mampu bersaing di dalam dunia kerja, serta dapat berperan bagi pembangunan.

Pengabdian kepada masyarakat adalah bentuk Kegiatan pengabdian kepada masyarakat yang merupakan salah satu Tri Dharma Perguruan Tinggi Selain Pendidikan dan Penelitian, sesuai Undang-Undang RI Nomor 20 Tahun 2003 tentang Sistem Pendidikan Nasional, pada Pasal 20 ayat 2 dinyatakan: "Perguruan Tinggi berkewajiban menyelenggarakan pendidikan, penelitian dan pengabdian masyarakat". Pada Pasal 24 ayat 2 disebutkan: "Perguruan tinggi memiliki otonomi untuk mengelola sendiri lembaganya sebagai pusat penyelenggaraan pendidikan tinggi, penelitian ilmiah, dan pengabdian masyarakat".

Pengabdian kepada masyarakat adalah suatu kegiatan yang bertujuan membantu masyarakat tertentu dalam beberapa aktivitas tanpa mengharapkan imbalan dalam bentuk apapun. Secara umum program ini dirancang oleh berbagai universitas atau institute yang ada di Indonesia begitu pula di Universitas Pamulang (UNPAM) untuk memberikan kontribusi nyata bagi bangsa Indonesia. Khususnya dalam pengembangan diri bagi pemuda karang taruna desa cidokom.

Fenomea yang terjadi dijaman sekarang adalah susahnya mencari lapangan pekerjaan dan penghasilan tambahan, maka dari itu dengan progam mengenai pengembangan diri melalui pelatihan dalam menghadapi pandemic covid-19 dengan tema "Pelatihan Pengembangan Diri Bagi Pemuda Karang Taruna Desa" akan meningkatkan kualitas 
SDM para pemuda karang taruna didesa cidokom.

Pengembangan diri adalah komponen terpenting untuk mencapai kehidupan yang luar biasa atau kesuksesan hidup seperti yang diinginkan oleh kebanyakan orang. Pengertian pengembangan diri atau personal development jarang diartikan sebagai suatu istilah. Secara singkat, pengembangan diri adalah menginvestasikan diri sendiri agar kita dapat mengontrol atau mengendalikan diri kita dengan sangat baik dan efektif.

Sedangkan menurut Erik Erikson, pengembangan diri adalah usaha yang dilakukan manusia dalam menghadapi rintangan emosional di dalam kehidupannya. Tujuan pengembangan diri adalah memaksimalkan segala potensi yang ada di dalam diri kita, sehingga kita dapat menjadi pribadi yang luar biasa dan mampu bertahan dengan segala perubahan zaman yang datang silih berganti.

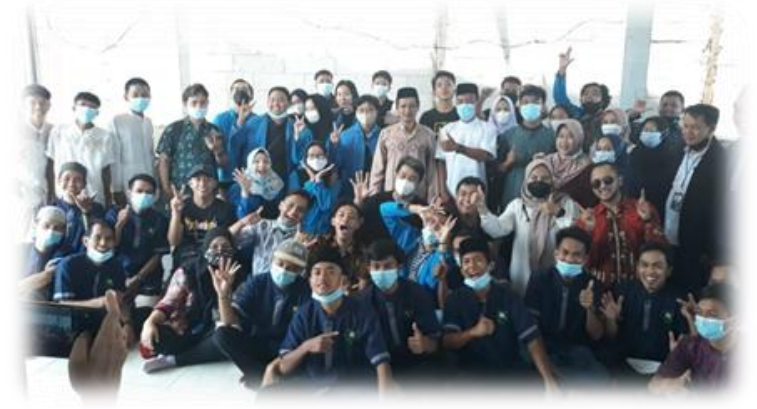

Gambar 1. Berfoto Bersama Peserta PKM

Organisasi Sosial wadah pengembangan generasi muda yang tumbuh dan berkembang atas dasar kesadaran dan tanggung jawab sosial dari, oleh dan untuk masyarakat terutama khususnya generasi pemuda di wilayah desa cidokom kecamatan Gunung sindur kabupaten Bogor Jawa Barat.

Karang Taruna adalah suatu organisasi sosial, perkumpulan sosial yang dibentuk oleh masyarakat yang berfungsi sebagai sarana partisipasi masyarakat dalam melaksanakan Usaha Kesejahteraan Sosial (UKS).

Karang Taruna tumbuh dan berkembang dari generasi muda, diurus atau dikelola oleh generasi muda dan untuk kepentingan generasi muda dan masyarakat di desa cidokom kecamatan Gunung sindur kabupaten Bogor Jawa Barat. Karenanya setiap desa/kelurahan atau komunitas adat sederajat dapat menumbuhkan dan mengembangkan Karang Tarunanya. Gerakannya di bidang Usaha Kesejahteraan Sosial (UKS) berarti bahwa semua upaya program dan kegiatan yang diselenggarakan Karang Taruna Desa ditujukan guna mewujudkan kesejahteraan sosial masyarakat terutama generasi mudanya.

\section{METODE}

Dengan menggunakan diskusi kelompok penyuluhan ini di harapkan untuk meningkatkan kualitas sumber daya manusia, Metode kegiatan ini adalah mendatangi Mushola dan para pemuda karang taruna desa tersebut dan memberikan sedikit wawasan dan diskusi akan pentingnya pelatihan dan pengembangan diri kepada pemuda karang taruna desa dan pengurus mushola juga kepada masyarakat sekitar.

\section{HASIL DAN PEMBAHASAN}

Pemberdayaan atau pelatihan ini bertujuan untuk meningkatkan kesejahteraan sosial. Kesejahteraan sosial dalam artian yang sangat luas mencakup berbagai tindakan yang dilakukan manusia untuk mencapai taraf kehidupan yang lebih baik

Materi penyuluhan adalah memberitahukan sebagai wadah pengembangan generasi muda, Karang Taruna Desa merupakan tempat diselenggarakannya berbagai upaya atau kegiatan untuk meningkatkan dan mengembangkan cipta, rasa, karsa, dan karya generasi muda dalam rangka pengembangan sumber daya manusia (SDM)., salah satu faktor penting untuk meningkatkan kualitas diri kita sebaga Sumber daya manusia adalah mengetahui dengan baik dan benar manfaat pengembangan diri sehingga terbuka pikiran serta tumbuh minat dan motivasi dalam diri mereka untuk meningkatkan kualitas diri.

Penyuluhan ini disampaikan dalam bentuk presentasi dan tanya jawab kepada peserta audience. kegiatan Pengabdian Kepada Masyarakat (PKM) di Mushola AnNur JL SDN Melati RT.03/03, Desa Cidokom, 
Parung, Cidokom, Kec. Gn. Sindur, Bogor.

Berikut adalah pembahsan materi :

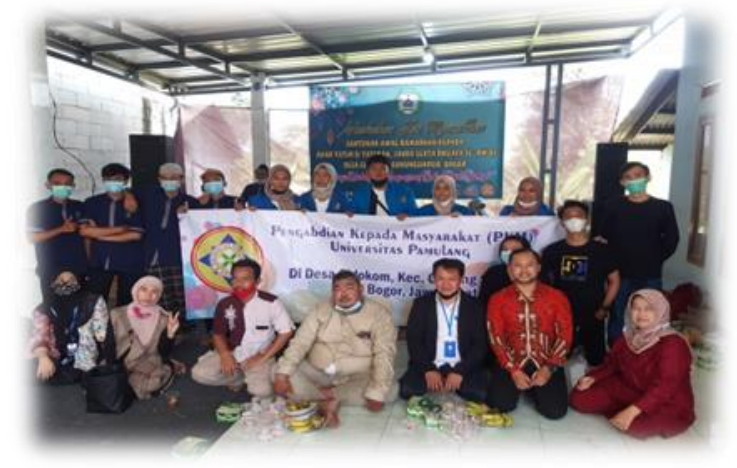

Gambar 2. Peserta PKM

1. Pemuda dapat diartikan sebagai individu dengan karakter yang dinamis, penuh semangat, optimis, memiliki daya juang, dan bergejolak.

Pada masa inilah pemuda bertransisi menjadi lebih matang untuk mengoptimalkan masa transisi pemuda dapat dioptimalkan dengan pemberdayaan potensi yang ada pada dirinya.

2. Tujuan dari pemberdayaan atau pelatihan pemuda ini tidak terlepas dari tujuan umum pemberdayaan masyarakat itu sendiri. Tujuan pemberdayaan masyarakat adalah untuk meningkatkan kesejahteraan sosial. Pemberdayaan (empowertment) masyarakat dan peningkatan kualitas hidup manusia atau peningkatan harkat dan martabat manusia.

3. Tahap-tahap Pemberdayaan Pemuda Wilson (Sumaryadi,2004) mengemukakan bahwa kegiatan pemberdayaan pada setiap individu dalam suatu organisasi, merupakan suatu siklus kegiatan yang terdiri dari :

a. Pertama, menumbuhkan keinginan pada diri seseorang untuk berubah dan memperbaiki, yang merupakan titik awal pemberdayaan.

b. Kedua, menumbuhkan kemauan dan keberanian untuk melepaskan diri dari kesenangan / kenikmatan dan hambatan-hambatan yang dirasakan, untuk kemudian mengambil keputusan mengikuti pemberdayaan demi terwujudnya perubahan dan perbaikan yang diharapkan`

c. Ketiga, mengembangkan kemauan untuk mengikuti atau megambil bagian dalam kegiatan pemberdayaan yang memberikan manfaat atau perbaikan keadaan.

d. Keempat, peningkatan peran atau partisipasi dalam kegiatan pemberdayaan yang telah dirasakan manfaatnya.

e. Kelima, peningkatan peran dan kesetiaan pada kegiatan pemberdayaan, yang ditunjukkan dengan berkembangnya motivasi untuk melakukan perubahan.

f. Keenam, peningkatan efektivitas dan efisiensi kegiatan pemberdayaan.

g. Ketujuh, peningkatan kompetensi untuk melakukan perubahan melalui kegiatan pemberdayaan baru.

4. Karang taruna sebagaimana tercantum adalam Peraturan Mentri Sosial RI No. 83/HUK/2005 adalah organisasi sosial sebagai wadah pembinaan dan pengembangan generasi muda yang tumbuh dan berkembang atas dasar kesadaran dan tanggung jawab sosial dari, oleh, dan untuk masyarakat terutama generasi muda di wilayah desa/kelurahan.

Dengan adanya karang taruna dimaksudkan sebagai wadah untuk menampung aspirasi masyarakat, khususnya generasi muda dalam rangka mewujudkan rasa kesadaran dan tanggung jawab sosial terhadap masyarakat pada umumnya. Tujuannya tidak lain adalah terwujudnya kesejahteraan social yang semakin meningkat bagi generasi muda. Untuk mencapai sasaran tersebut, tugas pokok karang taruna adalah bersama-sama dengan pemerintah dan komponen masyarakat lainnya untuk menanggulangi berbagai masalah kesejahteraan sosial terutama yang dihadapi generasi muda, baik yang bersifat preventif, rehabilitative, maupun pengembangan potensi generasi muda di lingkungannya. Terwujudnya pembangunan kesejahteraan sosial generasi muda di desa/kelurahan atau komunitas adat sederajat yang dilaksanakan secara komprehensif, terpadu dan terarah serta berkesinambungan oleh Karang Taruna bersama pemerintah dan komponen masyarakat lainnya. 


\section{PENUTUP}

Acara kegiatan pengabdian kepada masyarakat ini dilaksanakan selama 5 hari, yaitu sebagai berikut. Hari pertama dan kedua adalah meminta izin dari universitas dan camat dan dkm mushola cidokom, hari ketiga dan keempat adalah suvei tempat yang akan di pakai dalam pelaksanaan pengabdiaan kepada masyarakat, hari kelima adalah kegiatan penyuluhan mengenai pemanfaatan pelatihan pengembangan diri bagi pemuda karang taruna desa.

Dari paparan yang telah disampaikan terkait pelaksanaan kegiatan Pengabdian Kepada Masyarakat (PKM) Mahasiswa Prodi Manajemen Universitas Pamulang, yang bertempat di Lingkungan Mushola An-Nur, Desa cidokom, Kecamatan Gunung Sindur, Kabupaten Bogor. Jawa Barat, telah mendorong suasana kebersamaan dan semangat untuk bersama-sama meningkatkan dan mengembangkan cipta, rasa, karsa, dan karya generasi muda. Kerinduan masyarakat akan kehadiran dunia kampus tampak dalam pelaksanaan kegiatan tersebut.

\section{DAFTAR PUSTAKA}

Abdul Manaf, Teori dan Praktek Ekonomi Islam, Jakarta: Rineka, 1995

Abdurrahmat Fatoni, Metodologi Penelitian, Jakarta:Rineka Cipta, 2011

Ambar Tegu Sulistiyani, Kemitraan dan Model-Model Pemberdayaan Yogyakarta : Gava Media, 2017

Aziz Muslim, Metodologi Pengembangan Masyarakat, Yogyakarta, Penerbit TERAS : 2009

Basir Barthos, Manajemen Sumber Daya Manusia Suatu Pendekatan Makro, Jakarta:Bumi Aksara, 2009

Cholid Narbuko dan Abu Achmad, Metodologi Penelitian, Jakarta: PT Bumi Aksara, 2017
Dewanti, R. N., et al. (2021). Penyuluhan Dan Pelatihan Keterampilan Sablon Pigment Pasta Manual Di Karang Taruna 03 Desa Cisauk. Jurnal PADMA: Pengabdian Dharma Masyarakat, 1(1).

Dr. Aprilia Theresia, NTP, M. Si., et. al. Pembangunan Berbasis Masyarakat, Bandung: Alfabeta, 2014

Drs. Abu Huraerah, M.Si, pengorganisasian dan pengembangan masyarakat, Bandung : Humaniora, 2008

Eka, P. D., et al. (2020). Pengelolaan Keuangan Ponpes Dalam Rangka Peningkatan Masyarakat Mandiri Di Panti Asuhan Ikhwaniyah Cinta Yatim Dan Dhuafa.Jurnal Pengabdian Dharma Laksana, 3(1), 35-40.

Garry Dessler, Manajemen Sumber Daya Manusia, Jakarta:Indeks, 2003.

Goris Mustaqim, Heri Mohamad Tohari, Pemuda Membangun Bangsa dari Desa, Bandung: Synersia Publishing, 2010.

Isbandi Rukminto Adi, Pengembangan masyarakat sebagai upaya pemberdayaan masyarakat, Jakarta: PT. Raja Grafindo Persada, 2008.

Paeno, P., et al. (2020). Pemanfaatan Sampah Plastik Untuk Kerajinan Rumah Tangga Taman Belajar Kreatif Mekar Sari. BAKTIMAS: Jurnal Pengabdian pada Masyarakat, 2(1), 57-61.

Prof. Dr. Ir. Totok Mardikanto, M. S., Dr. Ir. H. Poerwoko Soebiato, M.Si., Pemberdayaan masyarakat dalam Perspektif Kebijakan Publik, Bandung: Alfabeta, 2017.

Suwanto, S., et al. (2020). Menggali Potensi, Memotivasi Dan Mengarahkan Generasi Muda Menyongsong Dunia Kerja Pada PKBM Cipta Tunas Karya Cipondoh Kota Tangerang. Jurnal Pengabdian Dharma Laksana,2(2), 132-136. 